\title{
PELAYANAN KONSUMEN PADA BENGKEL AGUNG MOTOR
}

\author{
Evy Ratnasari \\ Fakultas Ilmu Sosial dan Ilmu Politik Universitas Kapuas Sintang \\ Universitas Kapuas Sintang, Jln. Y.C.Oevang Oeray No.92 Sintang, Kalimantan Barat
}

\begin{abstract}
Abstrak: Kunci sukses agar pelanggan memilih jasa layanan bengkel adalah dengan memberikan kepuasan kepada pelanggan. Kepuasan tersebut dapat dicapai melalui pemberian layanan dan dukungan yang optimal kepada pelanggan. Kualitas pelayanan pada bengkel Agung Motor Nanga Pinoh sudah cukup baik, dimana pemilik selalu menekankan pada kualitas pelayanan prima, pemilik juga menekankan bahwa kepuasan pelanggan merupakan hal yang utama.
\end{abstract}

Kata Kunci : Pelayanan, Konsumen, Bengkel Motor.

Globalisasi membawa dampak yang besar bagi perkembangan dunia bisnis. Pasar menjadi semakin luas dan peluang ada dimana-mana, namun sebaliknya persaingan menjadi semakin ketat dan sulit diprediksikan. Kondisi ini menuntut perusahaan untuk menciptakan keunggulan kompetitif bisnisnya agar mampu bersaing secara berkesinambungan. Persaingan yang semakin ketat terjadi di dalam dunia otomotif khususnya produk sepeda motor karena produk ini merupakan alat transportasi darat yang paling dominan banyak dimiliki dan dibutuhkan oleh masyarakat. Memang tidak mudah menjadi yang terbaik, selain harus menyediakan kualitas terbaik juga ada faktor pola perilaku konsumen yang tidak mudah ditebak, apalagi di Indonesia yang terdiri dari banyak pulau, sehingga memiliki ragam pola perilaku yang berbeda pula.

Saat ini perkembangan industri otomotif di Indonesia sangat signifikan member dampak bagi dunia usaha, khususnya usaha dibidang otomotif. Pelaku usaha dibidang otomotif yang ingin berkembang dan memperoleh keunggulan kompetitif harus dapat memberikan produk berupa barang atau jasa yang baik dan berkualitas. Kepadatan aktivitas di jalan menuntut kenyamanan dalam berkendara. Untuk itu kendaraan yang digunakan harus selalu dalam keadaan baik. Agar kendaraan selalu dalam keadaan baik maka diperlukan perawatan dan service berkala. Untuk itu sangat dibutuhkan jasa bengkel. Bengkel service sepeda motor adalah usaha yang didirikan dengan tujuan menerima jasa perawatan dan perbaikan kendaraan sepeda motor.

Jasa sendiri dapat diartikan sebagai setiap tindakan atau kegiatan yang dapat ditawarkan oleh suatu pihak kepada pihak lain, pada dasarnya bersifat intangible (tidak berwujud fisik) dan tidak menghasilkan kepemilikan sesuatu. Jasa layanan pada bengkel sepeda motor antara lain service, ganti oli, modifikasi, spare part dan aksesoris. Kunci sukses agar pelanggan memilih jasa layanan bengkel adalah dengan memberikan kepuasan kepada pelanggan. Kepuasan tersebut dapat dicapai melalui pemberian layanan dan dukungan yang optimal kepada pelanggan. Pemberian layanan dan dukungan yang optimal itu dapat diberikan kepada pelanggan melalui pemberian layanan yang tepat dan berkualitas.

Pengaruh kemajuan ilmu pengetahuan dan teknologi telah meningkatkan kesadaran dan tuntunan masyarakat akan pelayanan yang baik, termasuk dalam hal ini adalah usaha di bidang bengkel yang akhir-akhir ini berkembang pesat, baik secara kualitas maupun kuantitas. Dapat kita lihat hampir disetiap jalan raya maupun wilayah perkampungan banyak tempat-tempat yang menyediakan jasa bengkel. Dengan banyaknya usaha dibidang perbengkelan ini menimbulkan persaingan yang semakin ketat antara satu bengkel dengan bengkel lainnya. Dengan adanya persaingan ini pula maka masing-masing bengkel berusaha meningkatkan jumlah pelanggan serta mempertahankan pelanggan agar tetap setia menggunakan jasanya dengan cara meningkatkan kepuasan pelanggan.

Kunci sukses agar pelanggan memilih jasa layanan bengkel adalah dengan memberikan kepuasan kepada pelanggan. Kepuasan tersebut dapat dicapai melalui pemberian layanan dan dukungan yang optimal kepada pelanggan. Banyaknya pesaing tidak menghalangi Bengkel Agung Motor untuk tetap bertahan, bahkan mampu berkembang pesat sampai sekarang ini. Memberikan pelayanan yang memuaskan bagi pelanggan merupakan visi dari Bengkel Agung Motor untuk tetap eksis di dunia perbengkelan. Bengkel Agung Motor mempunyai peluang dan tantangan seperti bengkel-bengkel pada umumnya. 
Pelanggan akan membandingkan layanan dan dukungan yang diberikan Bengkel Agung Motor dengan layanan dan dukungan yang mereka harapkan. Jika pelanggan merasa puas, maka pelanggan akan kembali lagi ke Bengkel Agung Motor dan menjadi pelanggan yang setia serta akan menceritakan pengalaman tersebut kepada orang lain, sehingga jumlah pelanggan Bengkel Agung Motor akan bertambah. Tetapi jika pelanggan merasa tidak puas, maka pelanggan akan mengeluhkan ketidakpuasannya tersebut kepada pihak bengkel Agung Motor.

Ketidakpuasan pelanggan atau keluhan pelanggan adalah suatu resiko pekerjaan yang tidak perlu dicemaskan, justru dengan adanya keluhan dan kekecewaan pelanggan, pihak perusahaan bisa lebih banyak belajar mengenal karakter pelanggan. Dengan kondisi tersebut, perusahaan dapat mencari solusi dalam mengatasi ketidakpuasan pelanggan. Mengenali kekecewaan atau keluhan pelanggan secara dini adalah suatu sikap bijaksana yang harus dilakukan perusahaan. Dengan demikian, perusahaan segera dapat mengantisipasi hal-hal yang tidak diinginkan yang dapat menjatuhkan bisnis yang tengah dijalankan perusahaan. Istilah pelayanan dalam bahasa Inggris adalah service. Moenir (2002:26-27) mendefinisikan "pelayanan sebagai kegiatan yang dilakukan oleh seseorang atau sekelompok orang dengan landasan tertentu dimana tingkat pemuasannya hanya dapat dirasakan oleh orang yang melayani atau dilayani, tergantung kepada kemampuan penyedia jasa dalam memenuhi harapan pengguna".

Pelayanan pada hakikatnya adalah serangkaian kegiatan, karena itu proses pelayanan berlangsung secara rutin dan berkesinambungan, meliputi seluruh kehidupan organisasi dalam masyarakat. Proses yang dimaksudkan dilakukan sehubungan dengan saling memenuhi kebutuhan antara penerima dan pemberi pelayanan. Selanjutnya Moenir (2002:16) menyatakan bahwa "proses pemenuhan kebutuhan melalui aktivitas orang lain yang langsung inilah yang dinamakan pelayanan. Jadi dapat dikatakan pelayanan adalah kegiatan yang bertujuan untuk membantu menyiapkan atau mengurus apa yang diperlukan orang lain". Berdasarkan definifi tersebut dapat dimaknai bahwa pelayanan adalah aktivitas yang dapat dirasakan melalui hubungan antara penerima dan pemberi pelayanan yang menggunakan peralatan berupa organisasi atau lembaga perusahaan. Menurut Kotler dalam Laksana (2008:78) pelayanan adalah "setiap tindakan atau kegiatan yanga dapat ditawarkan oleh suatu pihak kepada pihak lain, yang pada dasarnya tidak berwujud dan tidak mengakibatkan kepemilikan apapun".

Sedangkan Gronroos dalam Tjiptono (2005:66) menyatakan bahwa "pelayanan merupakan proses yang terdiri atas serangkaian aktivitas intangible yang biasa (namun tidak harus selalu) terjadi pada interaksi antara pelanggan dan karyawan, jasa dan sumber daya, fisik atau barang, dan sistem penyedia jasa, yang disediakan sebagai solusi atas masalah pelanggan". Sementara itu, menurut Lovelock, Petterson \& Walker dalam Tjiptono (2005:70) mengemukakan "perspektif pelayanan sebagai sebuah sistem, dimana setiap bisnis jasa dipandang sebagai sebuah sistem yang terdiri atas dua komponen utama: (1) operasai jasa; dan (2) penyampaian jasa".

Berdasarkan pengertian-pengertian diatas maka pelayanan merupakan suatu bentuk sistem, prosedur atau metode tertentu diberikan kepada orang lain, dalam hal ini, kebutuhan pelanggan tersebut dapat terpenuhi sesuai dengan harapan atau keinginan pelanggan dengan tingkat persepsi mereka. Menurut Payne (2000:79) mengatakan bahwa layanan pelanggan terdapat pengertian: Segala kegiatan yang dibutuhkan untuk menerima, memproses, menyampaikan dan memenuhi pesanan pelanggan dan untuk menindak lanjuti setiap kegiatan yang mengandung kekeliruan. Ketepatan waktu dan reabilitas penyampaian produk dan jasa kepada pelanggan sesuai dengan harapan mereka. Serangkaian kegiatan yang meliputi semua bidang bisnis yang terpadu untuk menyampaikkan produk dan jasa tersebut sedemikian rupa sehingga dipersepsikan memuaskan oleh pelanggan dan yang merealisasikan pencapaian tujuan-tujuan perusahaan. Total pesanan yang masuk dan seluruh komunikasi dengan pelanggan. Penyampaian produk kepada pelanggan tepat waktu dan akurat dengan tidak lanjut tanggapan keterangan yang akurat. Disamping itu adanya suatu sistem pelayanan yang baik terdiri dari tiga elemen, yakni: Strategi pelayanan, suatu strategi untuk memberikan layanan dengan mutu yang sebaik mungkin kepada para pelanggan. Sumber daya manusia yang memberikan layanan. Sistem pelayanan, prosedur atau tata cara untuk memberikan layanan kepada para pelanggan yang melibatkan seluruh fasilitas fisik yang memiliki dan seluruh sumber daya manusia yang ada.

Dalam penetapan sistem pelayanan mencakup strategi yang dilakukan, dimana pelayanan yang diberikan kepada pelanggan dapat merasakan langsung, agar tidak terjadai distorsi tentang suatu kepuasan yang akan mereka terima. 
Sementara secara spesifik adanya peranan pelayanan yang diberikan secara nyata akan memberikan pengaruh bagi semua pihak terhadap manfaat yang dirasakan pelanggan.

Menurut pandangan penulis layanan adalah suatu tindakan sukarela dari satu pihak ke pihak lain dengan tujuan hanya sekedar membantu.atau adanya permintaan kepada pihak lain untuk memenuhi kebutuhannya secara sukarela. Pelayanan adalah aspek yang tidak bisa disepelekan dalam persaingan bisnis manapun. Karena dengan pelayanan konsumen akan menilai kemudian menimbang apakah selanjutnya dia akan loyal kepada pemberi layanan tersebut. Hingga tak jarang para pebisnis memaksimalkan layanannya untuk menarik konsumen sebesar-besarnya.

Kualitas pelayanan (service quality) dapat diketahui dengan cara membandingkan persepsi para konsumen atas pelayanan yang nyata-nyata mereka terima / peroleh dengan pelayanan yang sesungguhnya mereka harapkan / inginkan terhadap atribut-atribut pelayanan suatu perusahaan. Jika jasa yang diterima atau dirasakan (perceived service) sesuai dengan yang diharapkan, maka kualitas pelayanan dipersepsikan baik dan memuaskan, jika jasa yang diterima melampaui harapan konsumen, maka kualitas pelayanan dipersepsikan sangat baik dan berkualitas.Sebaliknya jika jasa yang diterima lebih rendah daripada yang diharapkan, maka kualitas pelayanan dipersepsikan buruk.

Kualitas merupakan suatu kondisi dinamis yang berpengaruh dengan produk, jasa, manusia, proses dan lingkungan yang memenuhi atau melebihi harapan. Sehingga definisi menurut Tjiptono (2007:98) "kualitas pelayanan dapat diartikan sebagai upaya pemenuhan kebutuhan dan keinginan konsumen serta ketepatan penyampaiannya dalam mengimbangi harapan konsumen".

Menurut Kotler (2002:83) definisi pelayanan adalah "setiap tindakan atau kegiatan yang dapat ditawarkan oleh suatu pihak kepada pihak lain, yang pada dasarnya tidak berwujud dan tidak mengakibatkan kepemilikan apapun. Produksinya dapat dikaitkan atau tidak dikaitkan pada satu produk fisik. Pelayanan merupakan perilaku produsen dalam rangka memenuhi kebutuhan dan keinginan konsumen demi tercapainya kepuasan pada konsumen itu sendiri”. Kotler juga mengatakan bahwa perilaku tersebut dapat terjadi pada saat, sebelum dan sesudah terjadinya transaksi. Pada umumnya pelayanan yang bertaraf tinggi akan menghasilkan kepuasan yang tinggi serta pembelian ulang yang lebih sering. Kata kualitas mengandung banyak definisi dan makna, orang yang berbeda akan mengartikannya secara berlainan tetapi dari beberapa definisi yang dapat kita jumpai memiliki beberapa kesamaan walaupun hanya cara penyampaiannya saja biasanya terdapat pada elemen sebagai berikut: Kualitas meliputi usaha memenuhi atau melebihkan harapan pelanggan. Kualitas mencakup produk, jasa, manusia, proses dan lingkungan. Kualitas merupakan kondisi yang selalu berubah.

Dari definisi-definisi tentang kualitas pelayanan tersebut dapat diambil kesimpulan bahwa kualitas pelayanan adalah segala bentuk aktivitas yang dilakukan oleh perusahaan guna memenuhi harapan konsumen. Pelayanan dalam hal ini diartikan sebagai jasa atau service yang disampaikan oleh pemilik jasa yang berupa kemudahan, kecepatan, hubungan, kemampuan dan keramahtamahan yang ditujukan melalui sikap dan sifat dalam memberikan pelayanan untuk kepuasan konsumen.

Kualitas pelayanan (service quality) dapat diketahui dengan cara membandingkan persepsi para konsumen atas pelayanan yang nyata-nyata mereka terima/peroleh dengan pelayanan yang sesungguhnya mereka harapkan/inginkan terhadap atribut-atribut pelayanan suatu perusahaan. Hubungan antara produsen dan konsumen menjangkau jauh melebihi dari waktu pembelian ke pelayanan purna jual, kekal abadi melampaui masa kepemilikan produk. Perusahaan menganggap konsumen sebagai raja yang harus dilayani dengan baik, mengingat dari konsumen tersebut akan memberikan keuntungan kepada perusahaan agar dapat terus hidup.

Menurut Kotler dan Amstrong dalam Arief (2007:18) mengemukakan bahwa "jasa adalah seliap tindakan atau kegiatan yang dapat ditawarkan oleh suatu pihak kepada pihak lain yang pada dasarnya tidak berwujud dan tidak menyebabkan kepemilikan kepada sesuatu, yang dapat berhubungan dengan suatu produk fisik maupun tidak".Zeithamal dan Bitner dalam Hurriyati (2008:28) berpendapat bahwa "pengertian jasa adalah aktivitas ekonomi dengan output selain produk dalam pengertian fisik, dikonsumsi dan diproduksi pada saat bersamaan, memberikan nilai tambah dan secara prinsip tidak berwujud".

Berdasarkan kedua definisi tersebut, jasa dapat diartikan sebagai sesuatu yang tidak berwujud, yang melibatkan tindakan melalui proses dan kinerja yang ditawarkan oleh satu pihak ke 
pihak lain. Pada dasarnya jasa merupakan aktivitas ekonomi yang hasilnya tidak merupakan produk dalam bentuk fisik atau kontruksi, yang biasanya dikonsumsi pada saat yang sama dengan waktu yang dihasilkan dan memberikan nilai tambah, seperti kenyamanan atau pemecahan masalah yang dihadapi oleh konsumen.

Lovelock yang dikutip Wyckop dalam Arief (2007:118) bahwa "kualitas jasa adalah tingkat keunggulan yang diharapkan dan pengendalian atas tingkat keunggulan tersebut untuk memenuhi keinginan pelanggan". Dapat disimpulkan bahwa kualitas jasa adalah perbedaan atau ukuran selisih antara harapan pelayanan yang akan diterima oleh konsunien dengan pelayanan yang telah diberikan oleh penyedia jasa.

Menurut Zeithaml dan Berry yang dalam Arief (2007:19) "Secara umum jasa mempunyai beberapa karakteristik khusus dengan barang. Jasa mempunyai pengaruh besar dalam pemasarannya, yaitu tidak berwujud, tidak dapat dipisahkan antara proses produksi dengan konsumsi, mempunyai variabelitas yang tinggi, tidak dapat disimpan dan tidak menyebabkan suatu kepemilikan". Lima karakteristik pokok jasa yang membedakannya dengan produk barang. Tjiptono (2006:18-22) yaitu: Intangibility. Jasa berbeda dengan barang. jika barang merupakan suatu objek, alat, atau benda, makajasa adalah suatu perbuatan, kinerja (performance) atau usaha. Inseparability. Barang biasanya diproduksi, kemudian dijual, kemudian dikonsumsi. Sedangkan jasa dijual Terlebih dahulu, baru kemudian diproduksi dan dikonsumsi secara bersamaan. Variability. Jasa bersifat variabel karena merupakan non-standardized output, artinya banyak variasi bentuk, kualitas, dan jenis, tergantung kepada siapa, kapan, dan dimana jasa tersebut diproduksi. Perishability. Persihability berarti, jasa tidak tahan lama dan tidak dapat disimpan. Lack of ownership Merupakan perbedaan dasar antara jasa dan barang. Pada pembelian barang, konsumen memiliki hak penuh atas penggunaan dan manfaat produk yang dibelinya. Pada pembelian jasa, pelanggan memiliki akses personal atas suatu jasa untuk jangka waktu yang terbatas (misal: kamar hotel, bioskop, jasa penerbangan dan pendidikan).

Menurut Pasuraman, Zeithaml, dan Berry dalam Arif (2007:125, ada sepuluh kriteria umum atau standar yang menentukan kualitas suatu jasa (SERVQUAL), yaitu:

a. Fasilitas fisik (tangibles) yang dirasakan yaitu bukti fisik dari jasa bisa berupa fasilitas fisik, peralatan yang dipergunakan, representasi fisik dari jasa. b. Keandalan (Reliability) mencakup dua hal pokok, yaitu konsistensi kerja (performance) dan kemampuan untuk dipercaya (dependability).

c. Ketanggapan (Responeviness) yaitu kemauan atau kesiapan para karyawan untuk memberikan jasa yang dibutuhkan pelanggan.

d. Kemampuan (Competency) artinya setiap orang dalam suatu perusahaan memiliki keterampilan dan pengetahuan yang dibutuhkan agar dapat memberikan jasa tertentu.

e. Tata Krama (Courtesy) meliputi sikap sopan santun, respek, perhatian dan keramahan yang dimiliki para contact personel.

f. Sifat jujur (Credibility) yaitu sikap jujur dan dapat dipercaya. Kredibilitas mencakup nama perusahaan, reputasi, perusahaan, karakteristik pribadi, contact personel, dan intraksi dengan pelanggan.

g. Keamanan (Security) yaitu aman dari bahaya, resiko atau keragu-raguan.

h. Akses (Access) yaitu kemudahan untuk dihubungi dan ditemui. Hal ini berarti lokasi fasilitas jasa yang mudah dijangkau, waktu menunggu yang tidak terlalu lama, saluran komunikasi perusahaan mudah dihubungi.

i. Komunikasi (Communication) artinya memberikan informasi kepada pelangan dalam bahasa yang dapat mereka paham, serta selalu mendengarkan saran dan keluhan pelanggan.

j. Perhatian pada pelanggan (Understanding the Customer) yaitu usaha untuk memahami kebutuhan pelanggan.

Kualitas pelayanan merupakan kunci sukses bagi perusahaan dalam menghadapi era kompetisi yang semakin tajam. Parasuraman (2005:35) "Kualitas layanan adalah perbandingan dari harapan pelanggan dengan persepsi dari layanan nyata (actual performance) yang mereka terima". Kualitas layanan juga didefinisikan sebagai persepsi konsumen secara keseluruhan baik keunggulan dan kelemahan dari organisasi dalam layanannya. Menurut Parasuraman (2005:40) "ada dua faktor utama yang mempengaruhi kualitas jasa yaitu expected service (jasa yang diharapkan) dan perceived service (jasa yang diterima)". Apabila jasa yang diterima atau yang dirasakan sesuai dengan yang diharapkan, maka kualitas jasa dipersepsikan baik dan memuaskan. Jika jasa yang diterima melampaui harapan pelanggan, maka kualitas jasa dipersepsikan sebagai kualitas yang ideal. Sebaliknya jika jasa yang diterima lebih rendah dari pada yang diharapkan, maka kualitas jasa akan dipersepsikan buruk atau tidak memuaskan. Penilaian kualitas pelayanan jasa dalam model Servqual didasarkan pada skala multi 
item yang dirancang untuk mengukur harapan dan persepsi pelanggan, serta gap di antara keduanya dalam dimensi-dimensi utama kualitas jasa.

Menurut Kotler (2004:48) "Jasa merupakan setiap tindakan atau kegiatan yang dapat ditawarkan oleh suatu pihak kepada pihak lain, pada dasarnya bersifat. Menurut Parasuraman dalam Lupiyoadi dan Hamdani (2006:54) "bukti fisik (tangibles) yaitu kemampuan suatu perusahaan dalam menunjukkan eksistensinya kepada pihak eksternal. Penampilan dan kemampuan sarana dan prasarana fisik perusahaan yang dapat diandalkan serta keadaan lingkungan sekitarnya merupakan salah satu cara perusahaan jasa dalam menyajikan kualitas layanan terhadap pelanggan". Lingkungan kerja merupakan salah satu fungsi yang penting dalam manajemen sumber daya manusia (MSDM). Lingkungan kerja adalah semua keadaan yang ada di tempat kerja yang dapat mempengaruhi karyawan baik secara langsung maupun tidak langsung selain itu lingkungan kerja merupakan suatu komunitas tempat manusia berkumpul dalam suatu keberagaman serta dalam situasi dan kondisi yang berubah-ubah yang dapat mempengaruhi kinerja karyawan. Menurut Sutrisno (2009:118) "Lingkungan kerja juga dapat diartikan keseluruhan sarana dan prasarana kerja yang ada di sekitar karyawan yang sedang melakukan pekerjaan yang dapat mempengaruhi pelaksanaan pekerjaan, lingkungan kerja ini meliputi tempat bekerja, fasilitas, dan alat bantu pekerjaan, kebersihan, pencahayaan, ketenangan, termasuk juga hubungan kerja antara orang-orang yang ada di tempat tersebut".

Ketersediaan sarana dan prasarana yang ada sangatlah berpengaruh dalam mempercepat dan mempermudah pelayanan. Menurut Moenir (2002:117) "Sarana pelayanan adalah segala jenis peralatan, perlengkapan kerja dan fasilitas lain yang berfungsi sebagai alat utama atau pendukung di dalam pelaksanaan pekerjaan, dan juga berfungsi social dalam rangka memenuhi kebutuhan orangorang yang sedang berhubungan dengan orang dalam bekerja". Pengertian yang dikemukakan oleh Moenir jelas memberi arah bahwa sarana dan prasarana adalah merupakan seperangkat alat yang digunakan dalam suatu proses kegiatan, baik alat tersebut merupakan alat pembantu maupun alat utama. Selanjutnya menurut Moenir (2002:118) pada dasarnya sarana dan prasarana memiliki fungsi sebagai berikut:

a. mempercepat proses pelaksanaan pekerjaan sehingga dapat menghemat waktu;

b. meningkatkan produktivitas, baik barang dan jasa; c. hasil kerja lebih berkualitas dan terjamin;

d. lebih memudahkan/sederhana dalam gerak para pengguna/pelaku;

e. ketepatan susunan stabilitas pekerjaan lebih terjamin;

f. menimbulkan rasa kenyamanan bagi orangorang yang berkepentingan; dan

g. menimbulkan rasa puas pada orang-orang yang berkepentingan yang menggunakannya.

Sarana dan prasarana kerja dalam usaha bengkel merupakan faktor pendukung dalam pemberian pelayanan jasa bengkel sepeda motor. Menurut Robbins (2002:190) mengemukakan bahwa "keberhasilan suatu kegiatan sangat dipengaruhi oleh unsur-unsur pendukungnya yaitu mutu orang-orangnya serta sarana-sarana yang diperlukan". Sarana prasarana sebagai alat yang berfungsi mempercepat dan memperkuat bengkel melaksanakan kegiatannya. Menurut Moekijat (2003:5) mengemukakan bahwa "tidak dapat disangkal bahwa tersedianya sarana dan prasarana tertentu dalam penyelenggaraan rangkaian kegiatan oleh sekelompok manusia merupakan keharusan mutlak, tidak mungkin menjalankan roda administrasi tanpa sarana dan prasarana tertentu". Salah satu pendukung utama kelancaran pelaksanaan usaha jasa bengkel adalah tersedianya sarana dan prasarana atau peralatan kerja yang memadai, dalam arti dapat memenuhi kebutuhan yang diperlukan. Ketersediaan sarana dan prasarana yang ada juga harus sesuai dengan jenis atau sifat suatu pekerjaan.

Menurut Kaho (2002:186) "peralatan adalah setiap benda atau alat yang dipergunakan untuk memperlancar atau mempermudah pekerjaan atau gerak aktivitas". Dari dua pengertian tersebut, dapat dipahami bahwa fasilitas atau peralatan kerja merupakan barang, benda atau alat yang dipergunakan untuk mempermudah atau memperlancar suatu aktivitas tertentu sehingga dapat mencapai tujuan yang diinginkan. Menurut Kaho (2002:187) bahwa "fasilitas atau perlengjkapan kerja dianggap baik memiliki beberapa kriteria yaitu cukup dalam jumlah, efisien, efektif serta praktis dalam penggunaannya". Fasilitas atau perlengkapan kerja dikatakan cukup dalam jumlah apabila peralatan yang tersedia sebanding atau seimbang dengan volume kerja yang ada, atau sebanding dengan jumlah tenaga yang akan menggunakannya, atau sebanding dengan kebutuhan perusahaan. 
Peralatan dikatakan efisien jika output yang dikeluarkan haruslah maksimal sedangkan dari sudut input haruslah minimal. Atau dapat disebutkan suatu peralatan disebut efisien apabila penggunaannya tidak membuang-buang energi, waktu dan tepat untuk suatu tujuan. Peralatan dianggap efektif apabila penggunaannya membawa efek (akibat, pengaruh, keadaan) seperti yang diharapkan. Atau dengan kata lain peralatan yang efektif adalah yang tepat dan mempercepat pencapaian tujuan. Sedangkan peralatan dianggap praktis jika dalam penggunaannya mudah dan senang memakainya atau menggunakannya. Lingkungan kerja sebagai sikap, nilai, norma dan perasaan yang lazim dimiliki oleh karyawan sehubungan dengan organisasi mereka. Lingkungan kerja adalah kondisi atau situasi yang secara langsung maupun secara tidak langsung berpengaruh terhadap daya gerak dan kehidupan organisasi karena lingkungan kerja akan selalu mengalami perubahan.

Dengan kata lain lingkungan kerja dianggap sebagai kepribadian suatu perusahaan seperti yang dilihat oleh para karyawanya, jika para karyawan merasa lingkungannya tidak mendukung maka dapat diduga bahwa karyawan akan bertindak sesuai dengan anggapan ini, sekalipun pihak manager melakukan segala usaha untuk bersikap demokratis atau mementingkan karyawan. Menurut Nitisemito (2002:183) "Lingkungan kerja adalah segala sesuatu yang ada di sekitar para pekerja dan yang dapat mempengaruhi dirinya dalam menjalankan tugas-tugas yang di bebankan kepadanya".

Untuk meningkatkan produktivitas individual yang sekaligus meningkatkan produktivitas organisasional atau perusahaan maka keadaan lingkungan kerja harus senyaman mungkin. Keadaan lingkungan kerja yang baik memberikan kenyamanan kepada manusia yang bekerja didalamnya, sehingga mereka merasa bersemangat, bergairah dan memperoleh kepuasan dalam bekerja. Semangat, gairah dan kepuasan kerja diyakini merupakan cikal bakal dari peningkatan produktivitas. Lingkungan kerja adalah faktor yang sangat berpengaruh terhadap karyawan dalam menjalankan tugas dan pekerjaannya baik bekerja sebagai perorangan maupun sebagai kelompok dalam suatu ruangan atau kantor dalam menjalankan tugas yang dibebankan untuk memperoleh hasil yang dicapai. Mengingat manusia yang mempunyai karakteristik yang sangat heterogen, kebutuhan yang beragam, perasaan yang berlainan, emosi yang tidak sama dan masih banyak lagi unsur yang terdapat dalam jiwa dan fisik manusia yang memerlukan penanganan secara professional untuk membuat lingkungan kerja yang kondusif untuk bekerja.

Kebahagian karyawan terhadap lingkungan kerja memberi sinyal bahwa karyawan bergairah dan bersemangat dalam bekerja, hal itu dapat memberikan kepuasan dalam bekerja dan akhirnya mampu meningkatkan produktivitas kerja karyawan. Penciptaan lingkungan kerja yang sehat, baik dan meyenangkan akan mendorong perasaan dan kepuasan karyawan dalam bekerja, sehingga menumbuhkan semangat karyawan untuk bekerja lebih giat terhadap beban kerja yang diberikan dan tercapai dengan efektif dan efisien. Lingkungan kerja dapat diartikan pula sebagai faktor-faktor diluar manusia baik fisik mau pun non fisik dalam sesuatu organisasi.

Lingkungan kerja di dalam suatu perusahaan penting untuk diperhatikan oleh manajemen yang akan mendirikan perusahaan. Penyusunan suatu sistem produk yang baik tidak akan dilaksanakan dengan efektif apabila tidak didukung dengan lingkungan kerja yang memuaskan di dalam perusahaan tersebut. Segala peralatan yang dipasang dan dipergunakan di dalam perusahaan tersebut tidak akan banyak berarti, apabila para karyawan tidak dapat bekerja dengan baik disebabkan faktor lingkungan kerja yang tidak memenuhi persyaratan yang ditentukan. Walaupun lingkungan kerja itu tidak berfungsi, sebagai mesin dan peralatan produksi yang langsung memproses bahan menjadi produk, namun pengaruh lingkungan kerja ini akan terasa di dalam proses produksi yang dilaksanakan oleh perusahaan yang bersangkutan.

Menurut Harrianto (2010:178) "Lingkungan kerja adalah tempat dimana karyawan melakukan aktivitas setiap harinya. Lingkungan kerja yang kondusif memberikan rasa aman dan memungkinkan karyawan untuk dapat bekerja optimal". Menurut Lewa dan Subowo (2005:166) "Lingkungan kerja dapat mempengaruhi emosi karyawan". Jika karyawan menyenangi lingkungan kerja dimana dia bekerja, maka karyawan tersebut akan betah dalam melakukan aktivitas, sehingga waktu kerja dipergunakan secara efektif. Menurut Sedarmayanti (2009:201) "Lingkungan kerja itu mencakup hubungan kerja yang terbentuk antara sesama karyawan dan hubungan kerja antara bawahan dan atasan serta lingkungan fisik tempat karyawan bekerja"..

Menurut Sakitri (2009:120) "Lingkungan kerja dalam suatu perusahaan termasuk hal yang 
penting untuk diperhatikan. Meskipun lingkungan kerja yang memuaskan bagi karyawannya dapat meningkatkan kinerja, sebaliknya lingkungan kerja yang tidak memadai akan dapat menurunkan kinerja dan akhirnya menurunkan motivasi kerja karyawan". Menurut Supardi dalam Nurhaida (2010:190) "lingkungan kerja merupakan keadaan sekitar tempat kerja, baik secara fisik maupun non fisik yang dapat memberikan kesan yang menyenangkan, mengamankan, menentramkan, dan betah kerja.

Nitisemito (2002:154) mendefinisikan "lingkungan kerja adalah segala sesuatu yang ada di sekitar para pekerja yang dapat mempengaruhi dirinya dalam menjalankan tugas-tugas yang diembankan". Lewa dan Subowo (2005:186) menyatakan bahwa:lingkungan kerja didesain sedemikian rupa agar tercipta hubungan kerja yang mengikat pekerja dengan lingkungannya. Lingkungan kerja yang baik apabila karyawan dapat melaksanakan kegiatan secara optimal, sehat, aman dan nyaman. Lingkungan kerja yang kurang baik dapat menuntut tenaga kerja serta waktu yang lebih banyak dan tidak mendukung diperolehnya rancangan sistem kerja yang efisien. Dari beberapa pendapat di atas, disimpulkan bahwa lingkungan kerja merupakan segala sesuatu yang ada di sekitar karyawan pada saat bekerja, baik yang berbentuk fisik ataupun non fisik, langsung atau tidak langsung, yang dapat mempengaruhi dirinya dan pekerjaannya saat bekerja. Lingkungan kerja yang mendukung produktivitas kerja akan menimbulkan kepuasan kerja bagi pekerja dalam suatu organisasi.

Manajemen sumber daya manusia adalah suatu proses menangani berbagai masalah pada ruang lingkup karyawan, karyawan, buruh, manajer dan tenaga kerja lainnya untuk dapat menunjang aktifitas organisasi atau perusahaan demi mencapai tujuan yang telah ditentukan. Sumber Daya Manusia (SDM) adalah faktor sentral dalam suatu organisasi. Apapun bentuk serta tujuannya, organisasi dibuat berdasarkan berbagai visi untuk kepentingan manusia dan dalam pelaksanaan misinya dikelola dan diurus oleh manusia. Jadi, manusia merupakan faktor strategis dalam semua kegiatan institusi/organisasi. Selanjutnya, MSDM berarti mengatur, mengurus SDM berdasarkan visi perusahaan agar tujuan organisasi dapat dicapai secara optimum. Karenanya, MSDM juga menjadi bagian dari Ilmu Manajemen (Management Science) yang mengacu kepada fungsi manajemen dalam pelaksanaan proses-proses perencanaan, pengorganisasian, staffing, memimpin dan mengendalikan.
Peran sumber daya manusia (SDM) dalam menentukan keberhasilan perusahaan tidak bisa diabaikan. Ibarat pepatah, SDM merupakan sumber keunggulan daya saing yang tak lekang oleh panas, tak lapuk oleh hujan. Hal ini berbeda dengan teknologi produk dan proses produksi yang dinilai makin berkurang peran pentingnya sebagai sumber keunggulan daya saing. Dalam pemasaran jasa, kesuksesannya juga sangat bergantung pada SDM yang dimiliki. Apalagi dalam jasa, terjadi kontak antara SDM dengan konsumen secara langsung. Perusahaan juga harus mengantisipasi segala kemungkinan terjadinya permasalahan dalam pengelolaan SDM mulai dari tahap seleksi hingga proses manajemen SDM yang lebih kompleks. Pada usaha bengkel ini memandang penting peran SDM dalam memberikan kontribusi bagi kesuksesan bisnis perusahaan sehingga pengelolaan dan pengembangan asset sumber daya manusia merupakan bagian dari langkah strategis dalam upaya mencapai visi dan misi perusahaan. Program-program pengelolaan dan pengembangan SDM didasarkan pada standar kompetensi yang dibutuhkan untuk dapat bersaing dalam iklim bisnis yang kompetitif.

Dalam mencapai tujuannya tentu suatu organisasi memerlukan sumber daya manusia sebagai pengelola sistem, agar sistem ini berjalan tentu dalam pengelolaanya harus memperhatikan beberapa aspek penting seperti pelatihan, pengembangan, motivasi dan aspek-aspek lainya. Hal ini akan menjadikan manajemen sumber daya manusia sebagai salah satu indikator penting pencapaian tujuan organisasi secara efektif dan efisien.

Sumber daya manusia merupakan asset organisasi yang sangat vital, karena itu peran dan fungsinya tidak bisa digantikan oleh sumber daya lainnya. Menurut Tjutju (2008:121) "Betapapun modern teknologi yang digunakan, atau seberapa banyak dana yang disiapkan, namun tanpa sumber daya manusia yan professional semuanya menjadi tidak bermakna". Menurut Sumarsono (2003:4) Sumber Daya Manusia atau human recources mengandung dua pengertian, yaitu: SDM adalah usaha kerja atau jasa yang dapat diberikan dalam proses produksi. Dalam hal lain SDM mencerminkan kualitas usaha yang diberikan oleh seseorang dalam waktu tertentu untuk menghasilkan barang dan jasa. SDM menyangkut manusia yang mampu bekerja untuk memberikan jasa atau usaha kerja tersebut. Mampu bekerja berarti mampu melakukan kegiatan yang mempunyai kegiatan ekonomis, yaitu bahwa 
kegiatan tersebut menghasilkan barang atau jasa untuk memenuhi kebutuhan atau masyarakat.

Hariandja (2002:2) "Sumber Daya Manusia merupakan salah satu faktor yang sangat penting dalam suatu perusahaan disamping faktor yang lain seperti modal. Oleh karena itu SDM harus dikelola dengan baik untuk meningkatkan efektivitas dan efisiensi organisasi". Mathis dan Jackson (2006:3) "SDM adalah rancangan sistemsistem formal dalam sebuah organisasi untuk memastikan penggunaan bakat manusia secara efektif dan efisien guna mencapai tujuan organisasi”.

Demikian pula menurut The Chartered Institute of Personnel and Development (CIPD) dalam Mullins (2005:102) "Sumber daya manusia dinyatakan sebagai strategi perancangan, pelaksanaan dan pemeliharaan untuk mengelola manusia untuk kinerja usaha yang optimal termasuk kebijakan pengembangan dan proses untuk mendukung strategi". Hasibuan (2003:244) Pengertian Sumber Daya Manusia adalah "kemampuan terpadu dari daya pikir dan daya fisik yang dimiliki individu. Pelaku dan sifatnya dilakukan oleh keturunan dan lingkungannya, sedangkan prestasi kerjanya dimotivasi oleh keinginan untuk memenuhi kepuasannya".

SDM terdiri dari daya fikir dan daya fisik setiap manusia. Tegasnya kemampuan setiap manusia ditentukan oleh daya fikir dan daya fisiknya. SDM atau manusia menjadi unsur utama dalam setiap aktivitas yang dilakukan. Peralatan yang handal atau canggih tanpa peran aktif SDM, tidak berarti apa-apa. Daya pikir adalah kecerdasan yang dibawa sejak lahir (modal dasar) sedangkan kecakapan diperoleh dari usaha (belajar dan pelatihan). Kecerdasan tolok ukurnya Intelegence Quotient (IQ) dan Emotion Quality (EQ). Menurut Tjutju (2008:110) "Eksistensi sumber daya manusia dalam kondisi lingkungan yang terus berubah tidak dapat dipungkiri, oleh karena itu dituntut kemampuan beradaptasi yang tinggi agar mereka tidak tergilas oleh perubahan itu sendiri. Sumber daya manusia dalam organisasi harus senantiasa berorientasi terhadap visi, misi, tujuan dan sasaran organisasi di mana dia berada di dalamnya". Strategi pengembangan sumber daya manusia adalah suatu langkah yang penting dalam perusahaan karena dengan penggunaan strategi pengembangan yang tepat suatu perusahaan akan dapat maju dan berkembang. Strategi pengembangan sumber daya manusia dirancang untuk meningkatkan efisiensi dan efektifitas kerja, meningkatkan prestasi kerja, mengurangi absensi, serta memperbaiki kepuasan kerja. Para karyawan yang telah mendapatkan kecakapan serta kemampuan kerja melalui program pengembangan sumber daya manusia akan memperoleh hasil dan mutu yang lebih baik dalam melaksanakan tugas dan fungsinyaSumber daya manusia (SDM) merupakan aset atau modal paling penting bagi sebuah organisasi atau perusahaan. SDM dikatakan modal terpenting oleh karena memiliki nilai jauh melebihi semua peralatan, teknologi maupun sistem yang dimiliki organisasi maupun perusahaan itu sendiri.

\section{METODE PENELITIAN}

Metode penelitian yang digunakan dalam penelitian ini adalah metode penelitian dengan meng-gunakan pendekatan kualitatif, di mana penelitian yang dilakukan bersifat deskriptif. Narbuko \& Ach-madi (2004:44) memberikan pengertian penelitian yang berusaha untuk menuturkan pemecahan ma-salah yang ada sekarang berdasarkan data-data, jadi ia juga menyajikan data, menganalis dan menginter-pretasi, serta juga bisa bersifat komparatif dan ko-relatif.

Arikunto (2000:116) menyatakan "Subjek penelitian atau sasaran penelitian adalah satuan tertentu yang diperhitungkan sebagai subjek penelitian". Dalam penelitian sosial subjek penelitian adalah manusia. Subjek penelitian dalam penelitian terdiri dari: Pemilik Bengkel Agung Motor Nanga Pinoh Kabupaten Melawi. Karyawan Bengkel Agung Motor Nanga Pinoh Kabupaten Melawi. Konsumen Bengkel Agung Motor Nanga Pinoh Kabupaten Melawi, dalam menentukannya peneliti menggunakan teknik accidental sampling.

Dalam penelitiaan ini, peneliti menggunakan 2 teknik pengumpulan data, yaitu : Wawancara, Observasi, dan Studi Dokumentasi. Dalam mengumpulkan data-data penulis membutuhkan alat bantu (instrumen penelitian). Dalam penelitian ini peneliti menggunakan 3 alat bantu, yaitu : Pedoman wawancara; Pedoman Observasi; dan Menggunakan alat bantu untuk mengumpulkan informasi dan data, seperti handphone, flash disk, dan alat lainnya yang dapat membantu dan mendukung dalam pendokumentasian.

Peneliti mendapatkan data langsung dari subjek melalui wawancara mendalam (indepth inteviwer), dimana data tersebut direkam dengan handphone dibantu alat tulis lainya. Kemudian dibuatkan transkipnya dengan mengubah hasil 
wawancara dari bentuk rekaman menjadi bentuk tertulis secara verbatim. Data yang telah didapat dibaca berulang-ulang agar penulis mengerti benar data atau hasil yang telah di dapatkan.

\section{HASIL PENELITIAN DAN PEMBAHASAN}

Pemilik dan mekanik selalu berusaha untuk membangun komunikasi dengan konsumen yang memperbaiki sepeda motornya di bengkel. Komunikasi yang dilakukan semata-mata untuk membangun hubungan yang baik dengan konsumen, agar konsumen merasa nyaman untuk menyampaikan keluhan atas kerusakan kendaraannya. Selalu berkomunikasi dengan baik kepada konsumen guna membangun hubungan yang baik. Karyawan yang ada selalu menyapa konsumen dengan ramah dan sopan, dengan menanyakan hal-hal yang ringan sebagai upaya untuk membangun komunikasi yang baik antara karyawan dan konsumen, selama menunggu perbaikan sepeda motornya. Pemilik dan mekanik bengkel cukup ramah dan sopan dalam melayani konsumen. Sering terjadi komunikasi yang menyenangkan antara konsumen dengan pemilik, sehingga konsumen merasa nyaman untuk melakukan perbaikan sepeda motor di bengkel tersebut.

Pemilik bengkel selalu berusaha untuk membangun hubungan yang baik dengan pelanggan, diantaranya selalu membangun komunikasi yang baik dengan pelanggan dengan cara menyapa para konsumen dengan sapaan yang ramah dan sopan. Konsumen yang ada juga merasa nyaman dengan komunikasi yang terjadi sehingga mereka juga memberikan respon yang positif, sehingga terjadi komunikasi dua arah yang segar dan menyenangkan. Berdasarkan hasil penelitian diperoleh informasi bahwa telah ada upaya membangun hubungan yang baik dengan konsumen oleh pemilik dan mekanik Bengkel Agung Motor Nanga Pinoh, kondisi ini dapat dilihat dari adanya komunikasi yang baik antara pemilik kendaraan sebagai konsumen dengan pemilik maupun mekanik bengkel. Upaya yang dilakukan oleh pemilik dan mekanik bengkel memberikan pengaruh yang positif terhadap kepuasan konsumen, sehingga banyak pelanggan atau konsumen yang selalu memperbaiki sepeda motornya di bengkel tersebut.

Hal ini disadari oleh pemilik bengkel bahwa konsumen atau pelanggan harus selalu mendapatkan pelayanan yang terbaik, sehingga perlu dibangun hubungan yang baik dengan para pelanggan. Dengan banyaknya pelanggan tentu akan berpengaruh terhadap keuangan perusahaan yang dijalankan, sehingga juga akan memberikan keuntungan bagi perusahaan. Dalam menempatkan pelanggan pada tengah pusaran aktifitas bisnis, diharapkan perusahaan selalu memperhatikan dan mengutamakan pelanggan dalam segala aktifitas maupun program yang dilakukan. Sehingga pelanggan menjadi pihak yang selalu di dahulukan, dengan harapan akan merasa puas, nyaman, dan akhirnya menjadi loyal kepada perusahaan.

Karena pentingnya loyalitas terhadap kelangsungan hidup perusahaan, maka perusahaan harus secara kontinue menjaga dan meningkatkan loyalitas dari para pelanggannya. Oleh karena itu untuk membangun loyalitas pelanggan, perusahaan harus memiliki hubungan yang baik dengan pelanggan sehingga perusahaan dapat lebih memahami akan kebutuhan, keinginan dan harapan-harapan para pelanggannya. Pelayanan terhadap konsumen selalu diutamakan, dengan cara selalu memberikan pelayanan yang terbaik kepada para konsumen. Perbaikan sepeda motor pelanggan dilakukan dengan baik dan teliti sehingga keluhan terhadap kerusakan sepeda motor konsumen dapat diatasi dengan baik. Selain itu juga diberikan fasilitas pelayanan berupa kursi untuk para pemilik motor yang melakukan perbaikan sepeda motor di bengkel, ketersediaan suku cadang berbagai merk sepeda motor, sehingga pelanggan merasakan kenyamanan selama menunggu di bengkel.

Terhadap konsumen selalu diberikan pelayanan servis yang terbaik, sehingga konsumen merasa puas terhadap pelayanan yang diberikan. Namun ada kendala dalam pelayanan yang diberikan berupa keterbatasan karyawan yang ada, sehingga jika banyak pelanggan yang menginginkan perbaikan sepeda motor maka harus antri. Terhadap pelanggan yang antri maka perusahaan memberikan tempat menunggu dan disediakn air mineral sebagai upaya memberikan pelayanan yang baik pada pelanggan.

Pelayanan yang diberikan oleh bengkel Agung Motor sudah cukup baik, dimana selain pelayanan servis cepat juga tersedia onderdil sepeda motor berbagai merk, sehingga perbaikan yang dilakukan dapat segera dilaksanakan. Selain itu bengkel juga memiliki tenaga mekanik yang cukup berpengalaman sehingg servis sepeda motor yang dilakukan baik dan sesuai dengan kebutuhan konsumen.Untuk meningkatkan pelayanan kepada pelanggan atau konsumen, pihak perusahaan menyediakan spare part berbagai jenis sepeda motor yang banyak digunakan oleh masyarakat disekitar lokasi bengkel. Selain itu juga disediakan berbagai jenis aksesoris sepeda motor untuk menambah keindahan sepeda motor konsumen. 
Terhadap masyarakat sekitar yang dekat dengan bengkel dan merupakan pelanggan tetap, pihak bengkel juga memberika servis antar sepeda motor yang sudah selesai diservis atau diperbaiki. Terkadang pihak bengkel juga mau dipanggil ke rumah jika bengkel dalam keadaan sepia tau tidak ada konsumen yang mengantri. Ini dilakukan sebagai bentuk pelayanan prima kepada para konsumen sebagai pelanggan bengkel. Selain itu untuk memberikan pelayanan servis yang baik, pihak perusahaan juga mengirim mekanik untuk mengikuti pendidikan dan pelatihan ke Pontianak.

Sudah ada upaya peningkatan pelayanan dengan cara memberikan servis yang baik, memberikan kenyamanan kepada para konsumen yang mengantri, menyediakan spare part dan aksesoris yang lengkap, menyediakan air mineral untuk konsumen, serta menyediakan mekanik yang handal dengan cara memberikan kesempatan kepada mekanik untuk mengikuti pelatihan di Pontianak. Berbagai bentuk pelayanan yang diberikan ini dapat memberikan kepuasan kepada para konsumen yang memerlukan jasa bengkel.

Kepuasan Konsumen merupakan komponen penting untuk membantu keberhasilan strategi yang diambil perusahaan. Kepuasan Konsumen dapat menjelaskan mengapa pelanggan lebih memilih produk atau jasa yang ditawarkan oleh suatu perusahaan daripada perusahaan pesaing karena Kepuasan Konsumen merefleksikan pemikiran pelanggan terhadap perusahaan, baik itu merupakan penilaian mereka sendiri terhadap perusahaan secara keseluruhan maupun didapat dari membandingkan dengan perusahaan pesaing.

Pertumbuhan industri otomotif sepeda motor pada saat ini diyakini masih akan tetap menjadi industri yang cepat pertumbuhannya dengan industri lain. Tingginya tingkat penggunaan sepeda motor secara umum dapat dipandang sebagai kesempatan untuk memperluas market share. Namun perlu diingat bahwa karena tingginya tingkat persaingan, maka seorang pelanggan akan memiliki lebih dari satu preferensi penyedia jasa otomotif, dimana jasa otomotif yang dimaksud adalah bengkel sehingga sulit untuk menentukan tingkat kepuasan pelanggan.

Sektor layanan jasa pada bidang service sepeda motor semakin bersaing dewasa ini, dengan semakin banyaknya pesaing yang bergerak di bidang yang sama. Sektor jasa merupakan sektor yang paling besar mengalami perubahan sebagai akibat dari cepatnya perubahan yang dialami oleh faktor lain, seperti perubahan kebijakan dalam kaitan globalisasi serta perubahan teknologi baru yang secara langsung menaikkan iklim kompetisi dalam bidang industri.

Perhatian perusahaan terhadap kepuasan maupun ketidakpuasan pelanggan juga mulai semakin besar. Persaingan yang semakin ketat, dimana semakin banyak produsen yang terlibat dalam pemenuhan kebutuhan dan keinginan konsumen, menyebabkan setiap perusahaan harus menempatkan orientasi pada kepuasan pelanggan sebagai tujuan utama. Hal ini tercermin dari semakin banyaknya perusahaan yang menyertakan komitmennya terhadap kepuasan pelanggan dalam pernyataan misinya maupun publikasinya kepada konsumen.

Kepuasan konsumen hanya dapat tercapai dengan memberikan pelayanan yang berkualitas. Pelayanan yang baik sering dinilai oleh konsumen secara langsung dari karyawan sebagai orang yang melayani atau disebut juga sebagai produsen jasa, karena itu diperlukan usaha untuk meningkatkan kualitas sistem pelayanan yang diberikan agar dapat memenuhi keinginan dan meningkatkan kepuasan konsumen. Jadi kualitas pelayanan merupakan hal penting yang harus diperhatikan oleh perusahaan agar dapat tercapai kepuasan konsumen. Kualitas pelayanan memiliki hubungan yang erat dengan kepuasan konsumen. Kualitas memberikan suatu dorongan kepada konsumen untuk menjalin hubungan yang kuat dengan perusahaan.

Terhadap servis sepeda motor yang dilakukan di bengkel, selalu diberikan jaminan atas servis yang dilakukan sesuai dengan kondisi kendaraan. Dimana pihak bengkel akan memberikan informasi tentang kerusakan yang telah diperbaiki dan kemungkinan-kemungkinan yang bisa terjadi berkaitan dengan kerusakan yang ada. Pihak bengkel akan memberikan jaminan atas penggantian onderdil sepeda motor yang sudah dipasang untuk jangka waktu tertentu. Selain itu pihak bengkel akan memberikan informasi tentang tata cara perawatan sepeda motor agar tidak terjadi lagi kerusakan yang sama.

Pihak bengkel memberikan jaminan atas perbaikan yang dilakukan, selama belum terlalu lama, biasanya 1 hari. Pihak bengkel juga selalu memberikan tips atau cara merawat sepeda motor agar tidak terjadi kerusakan-kerusakan yang membuat sepeda motor tidak berfungsi.Pihak bengkel memberikan jaminan atas perbaikan atau servis yang dilakukan di bengkel, dengan cara memperbaiki kembali kesalahan servis yang 
dilakukan jika ada. Pihak bengkel juga selalu memberikan informasi yang baik kepada para pelanggan tentang bagaimana merawat sepeda motor dengan baik.

Jaminan yang diberikan perusahaan terhadap pelayanan yang diberikan merupakan suatu upaya untuk memberikan kepuasan kepada konsumen, sehingga konsumen yang ada akan menjadi pelanggan. Jaminan yang diberikan akan memberikan nilai tambah pada usaha jasa bengkel, kondisi ini akan memberikan kepercayaan kepada konsumen untuk melakukan servis sepeda motornya di bengkel. Kepercayaan konsumen terhadap suatu usaha jasa akan dipengaruhi oleh jaminan servis yang diberikan, dengan adanya jaminan servis ini maka konsumen akan merasa yakin untuk menggunakan jasa bengkel.

Pihak bengkel selalu mau mendengar keluhan konsumen terkait dengan servis yang telah dilakukan. Selain itu pihak bengkel juga mau mendengarkan keluhan konsumen berkaitan dengan kondisi kendaraannya, dan hal-hal apa yang harus dilakukan untuk memperoleh kenyamanan sepeda motornya. Setiap pelanggan atau konsumen yang menyampaikan keluhan akan dilayani dengan baik. Berbagai keluhan konsumen baik yang berkaitan dengan pelayanan servis yang dilakukan maupun dengan hal-hal lain yang berkaitan dengan sepeda motor akan dilayani dengan baik oleh pihak bengkel. Pihak bengkel selalu melayani komplain yang dilakukan konsumen terhadap servis yang dilakukan, dan pihak bengkel akan segera memperbaiki jika komplain tersebut jangka waktunya tidak terlalu lama dari servis yang telah dilakukan. Terhadap complain yang dilakukan oleh konsumen akan ditanggapi dengan baik oleh pihak bengkel dan akan dicarikan solusi-solusinya. Pihak bengkel akan memperhatikan keluhan atau complain yang dilakukan oleh konsumen terhadap jasa pelayanan yang diberikan, selama complain tersebut tidak lebih dari waktu yang sudah disepakati, biasanya tidak lebih dari 3 hari. Pihak bengkel akan memperbaiki selama pemakaian kendaraan yang diservis sesuai dengan kondisi umum pemakaian sepeda motor. Namun jika pemakaian kendaraan tidak sesuai dengan sebenarnya maka pihak bengkel tidak akan melayani keluhan atau complain dari konsumen.

Setiap organisasi yang berorientasi pada pelanggan perlu menyediakan kesempatan dan akses yang mudah dan nyaman bagi para pelanggannya guna menyampaikan saran, kritik, pendapat, dan keluhan mereka. Keluhan seharusnya dipandang sebagai kesempatan untuk belajar, meningkatkan pelayanan, dan mengetahui apa yang benar-benar pelanggan inginkan. Para pelanggan yang sampai mengeluh itu biasanya tertarik memberi kesempatan kepada perusahaan untuk meletakkan berbagai urusan dengan benar. Ini berarti bahwa jika perusahaan menangani keluhan secara efektif, perusahaan lebih mungkin tetap menguasai pelanggan dan memperbaiki hubungan yang akan berakibat pada loyalitas pelanggan.

Oleh karena itu, penanganan keluhan dapat mempengaruhi loyalitas dan retensi pelanggan. Apabila konsumen merasa puas dengan penanganan keluhan yang diberikan oleh perusahaan maka konsumen akan semakin loyal terhadap perusahaan karena merasa diperhatikan oleh pihak perusahaan. Lingkungan kerja di perusahaan cukup kondusif dan mampu meningkatkan kinerja karyawan yang ada, dimana dalam bekerja karyawan sudah memperoleh dukungan sarana dan prasarana yang sesuai dengan pekerjaannya. Selain itu suasana kerja juga cukup baik, hubungan karyawan dengan karyawan baik demikian pula hubungan antara karyawan dengan pemimpinan, sehingga karyawan merasa nyaman dalam bekerja. Secara umum kondisi lingkungan kerja di perusahaan sudah cukup memberikan dukungan terhadap pelaksanaan pekerjaan yang ada. Sudah tersedia sarana dan prasarana pendukung untuk melancarkan pekerjaan baik di kantor maupun di lapangan atau kebun.

Sudah tersedia sarana dan prasarana yang mendukung untuk menyelesaikan pekerjaan seharihari. Disamping itu juga selalu diciptakan hubungan yang harmonis antara karyawan, antar karyawan dengan mandor dan pimpinan, sehingga karyawan merasa nyaman dan tenang dalam bekerja. Lingkungan kerja yang ada pada Bengkel Agung Motor Nanga Pinoh cukup baik, dimana sudah tersedia sarana dan prasarana untuk menunjang kegiatan di bengkel. Selain itu pimpinan juga selalu berusaha menciptakan kondisi yang nyaman dalam bekerja, sehingga memberikan rasa puas dan senang kepada para karyawan dalam menyelesaikan pekerjaannya.

Bengkel Agung Motor Nanga Pinoh dalam menjaga kondisi kerja ini juga memperhatikan keamanan dan keselamatan kerja para karyawan yang ditentukan, seperti perusahaan melaksanakan syarat-syarat perlindungan kerja yang aman dan sehat, untuk memperkecil terjadinya kecelakaan dan penyakit diantara pekerja/karyawan. Pekerja/ karyawan harus mentaati perintah atasannya, memenuhi peraturan-peraturan tata tertib yang berhubungan dengan keselamatan kerja serta harus 
selalu berusaha untuk mencegah terjadinya sesuatu kecelakaan. Karyawan juga diharuskan menggunakan pakaian kerja yang sesuai dengan peruntukannya demi menjaga keselamatan kerja karyawan.

Jumlah karyawan adalah sebanyak 6 orang yang terdiri dari 5 orang montir dan 1 orang kasir.
Jumlah karyawan yang ada dirasakan sudah cukup memadai, sedangkan jika dilihat dari kualitas karyawan sudah cukup memadai, sebab sebagian besar karyawan yang ada adalah tenaga yang sudah cukup berpengalaman karena sudah cukup lama memiliki kemampuan sebagai montir sepeda motor. Hal ini dapat dilihat pada tabel berikut ini:

Tabel 1.Komposisi Karyawan Bengkel Berdasarkan Tingkat Pendidikan, Jenis Kelamin dan Jenis

\begin{tabular}{|c|c|c|c|c|}
\hline Nomor & Jenis Pekerjaan & Jenis Kelamin & Tingkat Pendidikan & Jumlah \\
\hline 1 & Montir & Laki-laki & SLTA/sederajat & 5 \\
\hline 2 & Kasir & Perempuan & SLTA/sederajat & 1 \\
\hline \multicolumn{4}{|c|}{ Jumlah } & 6 \\
\hline
\end{tabular}

Sumber: Bengkel Agung Motor Nanga Pinoh, 2017.

Karyawan yang ada sudah memiliki kemampuan untuk melakukan servis sepeda motor karena sebagian sudah berpengalaman dan sudah pernah mengikuti pelatihan. Jika dilihat dari jumlah dan kemampuan para karyawan sudah cukup memadai hal ini lebih didasarkan pada pengalaman kerja para karyawan yang ada. Karyawan yang ada sudah memiliki kemampuan dalam menyelesaikan tugas dan tanggung jawabnya, jumlahnya karyawan yang ada juga sudah dirasakan cukup memadai.

Kinerja karyawan yang ada sudah cukup baik, mereka sudah dapat menyelesaikan tugas dan tanggung jawabnya secara efektif dan efisien. Dalam memberikan pelayanan kepada para pemilik kendaraan bermotor dilakukan dengan baik dan ramah. Pelayanan yang cepat dan baik dari karyawan akan memberikan kesan yang baik pula di masyarakat, sehingga masyarakat atau pemilik kendaraan bermotor yang ingin memperbaiki atau menservis kendaraan bermotornya merasa senang karena pelayanan yang mudah, cepat dan baik hasil servis nya.

Dalam melakukan pekerjaan sehari-hari, pemilik selalu memotivasi karyawan yang ada untuk dapat memberikan pelayanan yang prima kepada masyarakat sebagai pelanggan yang akan memeriksakan kendaraan bermotornya. Para karyawan diharapkan selalu ramah, cekatan, dalam memberikan pelayanan sehingga masyarakat yang memerlukan pelayanan servis sepeda motor merasa terbantu.

Para karyawan yang ada sudah dapat menyelesaikan tugas dan tanggung jawab yang diberikan secara efektif dan efisien. Pimpinan selalu memantau kinerja karyawan terutama dalam memberikan pelayanan kepada pelanggan. Dalam memberikan pelayanan kepada para pemilik kendaraan bermotor yang melakukan servis atau perawatan kendaraan bermotornya, harus dilakukan dengan baik, cepat dan tepat, hal ini diharapkan dapat memberikan dampak positif kepada para pemilik kendaraan bermotor sebagai pelanggan.

Berdasarkan hasil penelitian diketahui bahwa karyawan bengkel Agung Motor sudah memiliki kemampuan dan keahlian dalam bidang tugasnya masing-masing, karyawan yang ada sudah dapat memberikan pelayanan yang baik, cepat, dan sesuai. Sebagian besar karyawan yang ada adalah karyawan yang sudah cukup bekerja sebagai montir, sehingga rata-rata karyawan sudah memiliki pengalaman yang cukup dalam melaksanakan pekerjaan yang menjadi tugas dan tanggung jawabnya.

Untuk memberikan pelayanan servis maupun perawatan kendaraan bermotor sangat dibutuhkan kompetensi karyawan atau montir yang mumpuni, dimana selain memiliki pengetahuan, keterampilan juga harus memiliki sikap yang baik dalam memberikan pelayanan secara langsung kepada pelanggan. Hal ini sejalan dengan pendapat yang mengatakan bahwa kompetensi tidak hanya mengandung pengetahuan, keterampilan dan sikap, namun yang penting adalah penerapan dari pengetahuan, keterampilan dan sikap yang diperlukan tersebut dalam pekerjaan. Kompetensi karyawan atau montir yang ada di bengkel Agung Motor merupakan faktor pendukung pelaksanaan pelayanan pengujian kendaraan bermotor. 


\section{KESIMPULAN DAN SARAN}

Kualitas pelayanan pada bengkel Agung Motor Nanga Pinoh sudah cukup baik, dimana pemilik selalu menekankan pada kualitas pelayanan prima, pemilik juga menekankan bahwa kepuasan pelanggan merupakan hal yang utama. Selain itu bengkel juga memberikan garansi atas servis yang sudah dilakukan oleh bengkel Agung Motor dalam jangka waktu tertentu. Sudah tercipta lingkungan kerja yang kondusif, dimana selain ketersediaan sarana dan prasarana penunjang kegiatan bengkel, lingkungan yang menyangkut kebersihan juga selalu dijaga. Selain itu selalu diciptakan suasana kerja yang nyaman sehingga hubungan antara karyawan yang ada sangat baik. Sumber daya manusia yang ada di bengkel Agung Motor Nanga Pinoh sudah memadai dan memiliki kompetensi sebagai montir, sehingga dapat memberikan pelayanan servis dan perawatansepeda motor dengan baik. Disaranakan, kualitas pelayanan yang sudah baik agar terus dipertahankan dan ditingkatkan, agar kepuasan pelanggan tercipta. Lingkungan kerja terus ditingkatkan, terutama sarana penunjang seperti ruang tunggu pemilik kendaraan yang lebih nyaman. Terus ditingkatkan kemampuan sumber daya montir yang ada dengan cara diikut sertakan dalam diklat montir, untuk mengimbangi dengan berkembangnya teknologi sepeda motor pada saat ini.

\section{DAFTAR PUSTAKA}

Arief. 2007.Pemasaran Jasa \& Kualitas Pelayanan. Malang:Bayumedia

Arikunto, S. 2000. Prosedur Penelitian Suatu Pendekatan Praktis. Jakarta: Rineka Cipta.

Hamdani. L. 2006. Manajemen Pemasaran Jasa, Edisi Kedua. Jakarta : Penerbit Salemba Empat.

Hariandja, Marihot T.E, 2002.Manajemen Sumber Daya Manusia. Jakarta: Grasindo.

Hasibuan, M.S.P. 2003. Manajemen Sumber Daya Manusia. Jakarta: Bumi Aksara.
Hurriyati, R. 2008.Bauran Pemasaran dan Loyalitas Konsumen. Bandung: Alfabeta.

Kaho, J.K. 2002. Prospek Otonomi Daerah di Negara Republik Indonesia. Jakarta: PT. Rajagrafindo Persada.

Kotler, P. 2002. Manajemen Pemasaran di Indonesia : Analisis, Perencanaan, Implementasi dan Pengendalian. Jakarta: Salemba Empat.

Kotler, P. 2004. Manajemen Pemasaran. Edisi Melinium. Jakarta: PT. Indeks Kelompok Gramedia, Jakarta.

Laksana, F. 2008.Manajemen Pemasaran. Yogyakarta: Graha Ilmu.

Lewa, K. dan Subowo. 2005. Pengaruh Kepemimpinan, Lingkungan Kerja Fisik dan Kompensasi Terhadap Kinerja Karyawan di PT. Pertamina (Persero) Daerah Operasi Hulu Jawa Bagian Barat Cirebon. Jurnal SINERGI: Kajian Bisnis dan Manajemen Edisi Khusus on Human Resources.

Mathis, R. L. dan Jackson J. H. 2006. Human Resource Management, alih bahasa. Jakarta: Salemba Empat.

Moekijat. 2009. Manajemen Sumber Daya Manusia. Bandung: Mandar Maju.

Moenir. 2002.Manajemen Pelayanan Umum Indonesia. Jakarta: Bumi Aksara.

Moleong, L.J. 2006. Metodologi Penelitian Kuantitatif. Bandung: PT. Remaja Rosdakarya.

Narbukodan Achmadi. 2004. Metode Penelitian. Jakarta: Bumi Aksara.

Nitisemito, A.S. 2002, Manajemen Personalia. Cetakan ke 9. Edisi ke 4. Jakarta: Ghalia Indonesia. 